\title{
Betrayal Aversion: Evidence from Brazil, China, Oman, Switzerland, Turkey, and the United States
}

\section{Citation}

Bohnet, Iris, Fiona Greig, Benedikt Herrmann, and Richard Zeckhauser. 2008. "Betrayal Aversion: Evidence from Brazil, China, Oman, Switzerland, Turkey, and the United States." American Economic Review 98 (1): 294-310. https://doi.org/10.1257/aer.98.1.294.

\section{Permanent link}

http://nrs.harvard.edu/urn-3:HUL.InstRepos:37865893

\section{Terms of Use}

This article was downloaded from Harvard University's DASH repository, and is made available under the terms and conditions applicable to Other Posted Material, as set forth at http:// nrs.harvard.edu/urn-3:HUL.InstRepos:dash.current.terms-of-use\#LAA

\section{Share Your Story}

The Harvard community has made this article openly available.

Please share how this access benefits you. Submit a story.

Accessibility 


\title{
Betrayal Aversion: Evidence from Brazil, China, Oman, Switzerland, Turkey, and the United States
}

\author{
By Iris Bohnet, Fiona Greig, Benedikt Herrmann, and Richard Zeckhauser*
}

\begin{abstract}
Due to betrayal aversion, people take risks less willingly when the agent of uncertainty is another person rather than nature. Individuals in six countries (Brazil, China, Oman, Switzerland, Turkey, and the United States) confronted a binary-choice trust game or a risky decision offering the same payoffs and probabilities. Risk acceptance was calibrated by asking individuals their "minimum acceptable probability" (MAP) for securing the high payoff that would make them willing to accept the risky rather than the sure payoff. People's MAPs are generally higher when another person, rather than nature, determines the outcome. This indicates betrayal aversion. (JEL C72, D81, Z13)
\end{abstract}

Risk aversion plays a central role in economic theory. It helps us understand why individuals insure and save, why investors do not place all their eggs in the basket offering the highest expected payoff, and why entrepreneurs earn a generous premium. But risk aversion alone may not account for people's willingness to take risk when the chance event is the action of another person rather than nature, for then additional considerations may enter.

We use the term "social risk" to describe situations where decisions by other human beings are the prime source of uncertainty. In this paper, we focus on the social risks involved when trusting another person, for example, a salesperson who may or may not describe a product accurately. In these trust situations, an individual (the principal) must decide whether to make herself vulnerable to another person (the agent). Traditional decision analysis, now well incorporated into economic theory, would tell us that for a rational, self-interested individual, "a risk is a risk is a risk." Assuming that there was no effect on future behavior, a decision maker facing the same payoffs and probabilities would make the same decision whether nature or the choice of another person resolves a lottery.

This paper examines whether individuals actually behave this way. Specifically, using a series of experiments, we compared individuals' willingness to take risks when the outcome is due to a chance device, as opposed to an identical odds-and-payoffs situation where the outcome depends on whether another player proves trustworthy. We found that people are generally less willing to take a risk when the source of the risk is another person rather than nature. We argue that this is due to what we label "betrayal aversion."

\footnotetext{
* Bohnet: Kennedy School of Government, Harvard University, 79 JFK Street, Cambridge, MA 02138 (e-mail: iris_bohnet@harvard.edu); Greig: Kennedy School of Government, Harvard University (e-mail: fiona_greig@ksgphd. harvard.edu); Herrmann: School of Economics, University of Nottingham, University Park, Nottingham, NG7 2RD, United Kingdom (e-mail: benedikt.herrmann@nottingham.ac.uk); Zeckhauser: Kennedy School of Government, Harvard University (e-mail: richard_zeckhauser@harvard.edu). Bohnet and Zeckhauser gratefully acknowledge the financial support provided by the Kokkalis Program, the Kuwait Program, and the Women and Public Policy Program at the Kennedy School of Government. Herrmann is grateful for the support provided by Simon Gaechter to conduct the research in Chengdu, and for helpful advice of Peter Wright. All authors are grateful for the provision of infrastructure for conducting the experiments by Bogazici University (Istanbul, Turkey), the Getulio Vargas Foundation (Rio de Janeiro, Brazil), the Southwest Jiaotong University (Chengdu, People's Republic of China), the Sultan Qaboos University (Muscat, Oman), and the University of Zurich (Zurich, Switzerland).
} 
Betrayal aversion has significant economic impact. Trust is a central element with every sales transaction, every professional relationship, every business transaction, indeed with any decision where one's outcome is not fully contractible and is partly under the control of another party. Trust has been associated with economic performance (see, e.g., the empirical literature started by Stephen Knack and Philip Keefer 1997, and Raphael LaPorta et al. 1997). Modern economies have many instruments, such as insurance and liability systems, to encourage trust by diminishing the material costs of betrayal. But if people are averse to being betrayed beyond the mere payoff consequences, it will be important to decrease the likelihood of betrayal as well, for example through incentives acting on reputations.

The risks of betrayal bear two major differences from natural risks. First, the decision situation usually involves payoffs to the other player. People may care about the payoffs going to the other person, positively or negatively. Such social preferences-see Ernst Fehr and Klaus Schmidt (2002) for a survey_could influence principals' decisions, making them either less or more likely to accept the social risk involved in trusting than a natural risk.

Second, elements beyond mere outcome-based preferences may enter the utility function. When the principal trusts the agent, she in effect gambles on the agent being trustworthy. If trust is violated, she may incur betrayal costs, a psychological loss above and quite apart from any material costs. Conversely, the principal may reap honor benefits if the agent is trustworthy. If principals are affected by such psychological benefits and costs, this could lead trust decisions to differ from risky choices offering the same stakes and odds. Such behavior would suggest that people care about how outcomes came to be, a notion first introduced into economics in a seminal paper by Matthew Rabin (1993).

If individuals have an aversion to betrayal, they will be less willing to take risks in a trust situation than in an equivalent situation where chance determines the outcome. We employ an experimental design that enables us to measure concerns about betrayal, about risk, and about payoffs to another player as revealed by choices made in real-money decisions. In contrast to earlier work on trust and risk (e.g., Catherine Eckel and Rick Wilson 2004; Fehr, Urs Fischbacher, and Michael Kosfeld 2005; Kosfeld et al. 2005), we do not directly compare behavior in a trust game and in a risky choice task. Both social and betrayal preferences, jointly referred to as "exploitation aversion" by Fehr, Fischbacher, and Kosfeld (2005), could lead people to behave differently in these two contexts as the two games differ not just in the agent of uncertainty, but also in the number of players involved who receive payoffs.

To distinguish between social preferences and betrayal aversion, we follow Bohnet and Zeckhauser (2004) and employ the "risky dictator game" (RDG). That game differs from a binary-choice trust game (TG) (Colin Camerer and Keith Weigelt 1988; David Kreps 1990) only in that nature (a chance device), rather than the agent, determines the payoffs going to the principal and the agent. Comparing willingness to take risk in these two games gives us a measure of betrayal aversion, our focus in this analysis. Comparing principals' choices in the risky dictator game and a "decision problem" (DP), a standard risky choice task where no second player is involved, gives us a measure, positive or negative, for social preferences. Finally, the decision problem itself allows us to observe people's attitudes toward risk.

Bohnet and Zeckhauser (2004) found that Americans care about betrayal. This paper, building on that effort, introduces the concept of betrayal aversion. It seeks to examine whether betrayal aversion is a robust phenomenon beyond the United States. Thus, we included individuals from a highly diverse set of countries in our sample. The outcome was uncertain. Given the mounting evidence of cross-country differences in what once were believed to be general phenomena, it is crucial for experimenters to test whether behavioral regularities do generalize broadly. For example, psychologists only relatively recently realized that two central concepts, the "fundamental attribution error" and "cognitive dissonance reduction" were not universal phenomena. (For a 
review of that literature, see Ziva Kunda 1999, chap. 11.) Similarly, social preference phenomena, such as fairness and cooperation, thought to be universal by many behavioral economists, have been shown to depend on context (e.g., Alvin E. Roth et al. 1991; Joseph Henrich et al. 2004).

In addition to the United States, where we had run our earlier experiments, we include Brazil, China, Oman, Switzerland, and Turkey in our sample. ${ }^{1}$ We assess the presence of betrayal aversion when controlling for some basic demographic characteristics, such as country of origin, gender, age, wealth, and whether a subject majored in economics. To test whether the extent of betrayal aversion in any of these countries differed from our sample average, we apply bootstrap procedures. Our central finding is that across these six countries individuals are betrayal averse: they are less willing to accept a gamble offering the same odds and payoffs when an agent rather than nature determines the outcome. Though our sample sizes are relatively small, looking at the countries individually, betrayal aversion is statistically significant for four of our six countries. It is more pronounced in Oman than in the rest of our sample.

Our results on betrayal aversion accord with recent findings in social psychology, organizational behavior, and neuroscience. Work by Jonathan J. Koehler and Andrew Gershoff (2003) suggests that people are deeply concerned about betrayal. Their recent survey on criminal and product safety betrayals found that subjects felt worse and imposed larger (hypothetical) punishments on intentional betrayals than on accidental nonfulfillments that had the same payoff consequences. Intentional betrayals violate a duty or break a promise, which produces a second source of utility loss to the principal. Research on psychological contracts suggests that in organizations, such utility losses may decrease a person's job satisfaction, lead to retributive actions, and in the extreme to exit (Sandra L. Robinson and Elizabeth Wolfe Morrison 2000). Finally, recent findings in neuroscience provide evidence for the more general concept of exploitation aversion. Kosfeld et al. (2005) dispensed the neuropeptide oxytocin, which has been shown to promote prosocial behavior in animals, to their subjects. Subjects given oxytocin took the social risk involved in trusting more readily, but not the natural risk involved in a risky-choice task.

Our paper is organized as follows. Section I introduces the experimental design, Section II shows how we measure our preference phenomena and makes predictions, Section III presents the results, and Section IV discusses some implications of our findings and concludes.

\section{Experimental Design}

Following the design introduced by Bohnet and Zeckhauser (2004), we focus on binary-choice tasks in three decision situations: the trust game, the risky dictator game, and the decision problem. In each, the principal had to choose between a sure thing and a lottery. The sure strategy resulted in a sure outcome, whereas the lottery could yield the principal either a higher ("good") or a lower ("bad") payoff than the sure outcome. Figure 1 presents our three games with the payoff structures employed in each.

In the trust game, choosing the lottery meant that the principal allowed the agent to determine the final payoffs. A money-maximizing agent would prefer 22 points to 15 , and thus should betray trust, given that chance. Anticipating such behavior, a money-maximizing principal should choose the sure thing, producing the Nash equilibrium of $(10,10)$, and thus receive 10 rather than 8. In the risky dictator game, the payoffs are the same, but nature (a random device)

\footnotetext{
${ }^{1}$ In our initial paper, we reported data from the United Arab Emirates (UAE) rather than Oman. We replaced the UAE by Oman, a neighboring Gulf state, because a referee correctly objected to the nonparallel nature of the UAE experiments, which had to be run in same-sex groups, as higher education there is segregated by gender. In Oman, we were able to run our experiments in mixed-sex groups.
} 


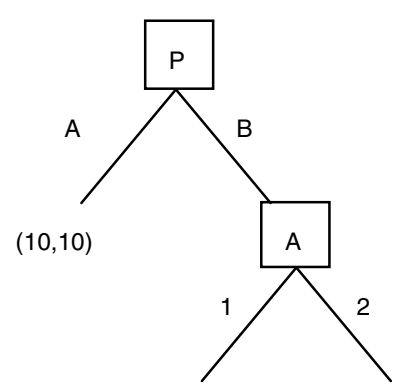

$(15,15)$
$(8,22)$

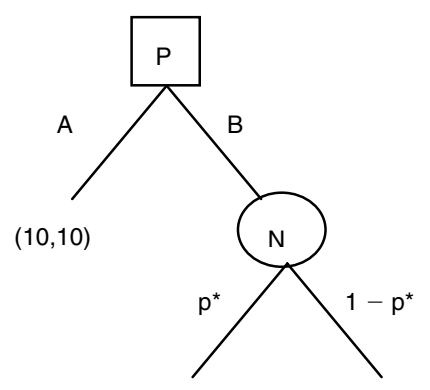

$(15,15)$
$(8,22)$
(10)

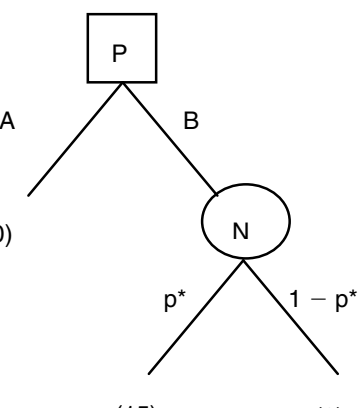

(15)

(8)

Trust Game

Risky Dictator Game

Decision Problem

$\mathrm{P}=$ Principal $\quad \mathrm{A}=$ Agent $; \mathrm{N}=$ Nature

Figure 1. Experimental Games (Payoff to Principal, Payoff to Agent)

and not the agent determines final payoffs if the principal chooses the lottery. In the decision problem, as well, nature chooses, but there is no agent, hence no payoffs to a second person.

To calibrate risk acceptance in a given decision situation, we asked principals their "minimum acceptable probability" (MAP) for securing the high payoff that would make them willing to accept the risky rather than the sure payoff. For example, in the trust game we posed the following question to principals (in neutral language): "How large would the probability $p$ of being paired with Person $Y$ [an agent] who chose Option 1 [to be trustworthy] minimally have to be for you to pick Alternative B [the lottery] over Alternative A [the sure thing]?" In the trust game, we simultaneously asked agents whether they would be trustworthy if given the opportunity (strategy method). Sample instructions are included in Appendix A1.

We used the agents' responses to determine the proportion of trustworthy agents, that is, the probability that if a principal trusted she would have her trust rewarded. We labeled this probability $p^{*}$, with a separate $p^{*}$ computed from each session of the trust game. Then we returned to each individual principal. She was informed of $p^{*}$. If her MAP was less than or equal to the $p^{*}$ in her session, she was assumed to trust. The outcome then depended on the prior decision of the agent with whom she was paired. She thus had a $p^{*}$-chance of receiving the good outcome, or more precisely, a $p^{*}$-chance of having been paired with an agent who chose to be trustworthy. If her MAP exceeded $p^{*}$, her demands were too high and she and her agent each got the sure outcome of ten points. Principals were informed of this procedure, in particular, that the value of their MAP relative to $p^{*}$ would be used to decide whether they trusted or whether they took the sure outcome. Agents knew only that principals had to make a decision between the sure thing and trust but were not informed on the specifics of the $M A P$-procedure, or that their decision would help determine $p^{*}$.

Principals in the risky dictator game and in the decision problem were told that $p^{*}$ had been determined prior to the experiment, but not how. For each country, its $p^{*}$ corresponded to the percent of all agents who had chosen to be trustworthy in the trust game in that country. ${ }^{2}$ After the principals had made their decisions, we revealed the value of $p^{*}$. As in the trust game, if a

\footnotetext{
${ }^{2}$ In practice, the value of $p^{*}$ was written on a slip hidden in an envelope visibly posted on the blackboard. In each country, the trust game sessions were run first.
} 
principal's $M A P$ was less than or equal to $p^{*}$, she was assumed to opt for the lottery, which gave her a $p^{*}$-chance of winning the high payoff. If her MAP was higher than $p^{*}$, she was assumed to opt for the sure outcome and earned the sure payoff. We resolved any lotteries by drawing a ball from an urn with $\left(p^{*}\right) 100$ green balls and $\left(1-p^{*}\right) 100$ blue balls.

The higher a principal's $M A P$, the higher $p^{*}$ had to be for her to choose the risky strategy over the sure thing. Thus, the less one likes one or both outcomes flowing from the risky strategy, the higher will be one's MAP. This mechanism is incentive compatible: a rational principal should be indifferent between the sure thing and the gamble with her reported MAP, since individuals cannot affect the probability they receive in the lottery. Given our procedure, assuming that a principal adheres to the Substitution Axiom of von Neumann-Morgenstern utility, truth-telling is a dominant strategy. ${ }^{3}$

\section{A. Experimental Procedures}

This study involved 688 new subjects in addition to the 145 subjects who had participated in our earlier study in the United States (Bohnet and Zeckhauser 2004), or 833 in total. The new 688 subjects included 192 in Brazil (98 in TG, 64 in RDG, 30 in DP), 108 in China (42 in TG, 42 in RDG, 24 in DP), 126 in Oman (58 in TG, 44 in RDG, 24 in DP), 120 in Switzerland (50 in TG, 48 in RDG, 22 in DP), and 142 in Turkey (70 in TG, 42 in RDG, 30 in DP). ${ }^{4}$ All were randomly recruited students at universities. Subjects were anonymous in all experiments, identified only by code numbers. The payoffs in points were presented to subjects in a matrix form with neutral terminology. Each point was converted to 1 Brazilian real, 1.5 Chinese yuan renminbi, 0.2 Omani rial, 1 Swiss frank, 0.75 new Turkish lira, or 1 US dollar at the end of the experiment. Monetary amounts were scaled for parity, using the hourly wage of a student research assistant as the common metric. Subjects earned a 10-point show-up fee and received on average an additional 13 points for an experiment that took approximately 30 to 40 minutes.

To ensure the equivalence of experimental procedures across countries, we followed Roth et al. (1991) on appropriate designs for multinational experiments. Thus, we controlled for currency, language, and experimenter effects to the best of our ability. We had the instructions translated (and back-translated) from English to Portuguese, Chinese, Turkish, and Arabic. (The experiments in Switzerland were conducted in English.) The experiments in Switzerland were conducted by the first-listed author; the experiments in Brazil by the second, and the experiments in China, Oman, and Turkey by the third. Each of these authors ran experimental sessions in the United States, where no experimenter effects were found.

We employed a between-subjects design where each subject participated in one game only. In the trust game and the risky dictator game, subjects were randomly assigned a role, and then randomly matched with a counterpart. In the decision problem, all subjects were principals. We

\footnotetext{
${ }^{3}$ It is strictly dominant if people assign positive probability to values of $p^{*}$ in the immediate neighborhood of their $M A P$. Our procedure is related to the Becker-DeGroot-Marshak elicitation procedure, but unlike it, we do not generate $p^{*}$ randomly from a uniform distribution. Note that the value of $p^{*}$ in the trust game may have been thought to be more (or less) uncertain — ambiguous in the terminology related to the Ellsberg Paradox (Daniel Ellsberg 1961)—than that for the risky dictator game or the decision problem. But this should have no effect on the principal's reported MAP. A $M A P$ is a cutoff value relating to preferences, and the estimated value of $p^{*}$ should not affect it; i.e., the procedure is incentive compatible even when principals are ambiguity averse. Similarly, principals' beliefs about $p^{*}$ may have differed between our games. For example, they may have expected a lower $p^{*}$ in the games against nature than in the trust game because of "mean experimenters" (much like in the "mean Monty" games; see, e.g., Dolly Chugh and Max H. Bazerman 2007). The same reasoning as above applies here: our procedure remains incentive compatible; the MAP should not be affected.

${ }^{4}$ We ran a total of 35 sessions; 4 TG-, 3 RDG-, and 1 DP-session in Brazil; 2 TG-, 2 RDG-, and 1 DP-session in China; 2 TG-, 2 RDG-, and 1 DP-sessions in Oman; 2 TG-, 2 RDG-, and 1 DP-session in Switzerland; 3 TG-, 2 RDG-, and 2 DP-sessions in Turkey; and 2 TG-, 2 RDG-, and 1 DP-session in the United States.
} 
chose a between-subjects rather than a within-subjects design because pilot studies had shown that people tended to anchor on the first game presented. Given these strong order effects and the complexity of our design, we chose the simpler format of a between-subjects design, where subjects were confronted with only one task at a time.

To ensure that subjects understood the experimental procedures and their impact on their earnings, they had to successfully complete a quiz testing their understanding. We confronted principals with various hypothetical values of $p^{*}$ and individual MAPs, and in each scenario asked whether final outcomes would be determined by their agent (a draw from the lottery), and what payoff consequences would result from the agent's choice (lottery outcome). Agents were asked to indicate the payoff consequences of their possible choices. Only after all subjects understood the problem and could calculate their earnings for different values of hypothetical MAPs and $p^{*}$ did we proceed with the experimental decision.

After subjects had made their decisions, they completed a short questionnaire that collected basic information on demographic characteristics. In all countries, we were allowed to collect information on our subjects' gender, age, wealth, and study concentration. In our complete sample, 49 percent of the subjects were female, the average age was 23 (with a standard deviation of 5 years), and 30 percent were concentrating in economics. On a self-assessed scale from 1 (poor) to 6 (wealthy), with a 3.36 average, 56 percent of the subjects reported themselves as coming from a family with average wealth or below, and 44 percent reported coming from an aboveaverage-income family. After each experiment, we informed all subjects on the details of the experimental procedure and the results. Subjects presented their code number to collect a sealed envelope containing their earnings.

\section{Preference Phenomena: Measurement and Predictions}

To measure betrayal, social, and risk preferences, we compared MAPs across the three decision situations. The three sets of $M A P \mathrm{~s}$ and $p^{\prime}$, the value of $p$ that makes the lottery actuarially fair, are the vital ingredients for our analysis. The difference between the MAPs in the trust game and the MAPs in the risky dictator game measures how much more willing principals are to take a risk against nature than to take the same risk relying on the trustworthiness of their agents. We take this magnitude to measure betrayal aversion, the net effect of the expected costs of betrayed trust less the expected benefits from honored trust.

Clearly, betrayal aversion matters only if principals care not only about outcomes but also about how outcomes came to be. ${ }^{5}$ In line with psychological attribution theories (e.g., Fritz Heider 1958; Arie W. Kruglansky 1979), recent theoretical models and empirical evidence in economics suggest that people respond to what actions, given certain choice sets, reveal about their counterpart's intentions (e.g., Rabin 1993; Sally Blount 1995; Kevin A. McCabe, Mary L. Rigdon, and Vernon L. Smith 2003; Martin Dufwenberg and Georg Kirchsteiger 2004; and Armin Falk and Fischbacher 2006). In the risky dictator game and the trust game, the same set of strategies is available respectively to nature and to the agent: either of them can either produce a good or a bad outcome for the principal. However, nature does not choose, but agents do. Thus, no malevolent motives are attributed to nature if a random device produces a bad outcome, but the same bad outcome will impose a psychological cost when a person is responsible for it.

Building on these findings, the notion of betrayal aversion suggests that people are willing not only to sacrifice their own income to reward (punish) those who were being kind (unkind) to them, but also to avoid experiences viewed as unkind or unfair. This seems intuitive as, for

\footnotetext{
${ }^{5}$ While not the focus here, this is also in line with procedural utility (e.g., Bruno S. Frey, Matthias Benz, and Alois Stutzer 2004).
} 
example, in Rabin's (1993) model, the ability to punish only partly makes up for the loss in welfare experienced when treated badly (p. 1287).

To see this more easily, we use von Neumann-Morgenstern utilities and assign 1 to the good outcome of 15, 0 to the bad outcome of 8 , and $s$ to the sure outcome of 10 in the risky dictator game. Thus, $s$ corresponds to the MAP in the risky dictator game, where $0<s<1$. The utility of the bad outcome when it is due to betrayal in the trust game is scaled as $-b$. We then have $M A P_{T G}(1)+\left(1-M A P_{T G}\right)(-b)=s$. This implies that $M A P_{T G}=(s+b) /(1+b)$ in the trust game. This contrasts with the risky dictator game, where $M A P_{R D G}=s$.

We expect $b>0$. If so, principals will have a higher MAP in the trust game than in the risky dictator game, thereby indicating betrayal aversion. Our empirical hypothesis is that average betrayal aversion, as measured by the difference between the mean MAP in the trust game and that in the risky dictator game, will be positive: $\overline{M A P}_{T G}-\overline{M A P}_{R D G}>0$.

The difference between the $M A P \mathrm{~s}$ in the decision problem and the MAPs in the risky dictator game reveals how much more principals are willing to accept a lottery when another player will gain as well. We label this as their social preference, which could be positive or negative. Recent theoretical models and much empirical evidence suggest that principals may be motivated by outcome-based preferences such as altruism (James Andreoni and John Miller 2002), efficiency gains to the dyad (Gary Charness and Rabin 2002), and concerns about disparities in payoffs, i.e., inequality aversion (Fehr and Schmidt 1999; Gary Bolton and Axel Ockenfels 2000). For the numerical payoffs we employ, altruism and efficiency preferences would lead a principal to prefer the lottery in the risky dictator game to the lottery in the decision problem. Inequality aversion would reverse this preference, leading to a higher MAP in the risky dictator game than in the decision problem. The net influence of the two effects is unclear, and might well depend on the size of the payoffs. Accordingly, we make no prediction about the sign of social preferences $\left(\overline{M A P}_{D P}-\overline{M A P}_{R D G}\right)$.

The difference between the MAPs in the decision problem and $p^{\prime}$ indicates principals' risk aversion (John W. Pratt 1964; Kenneth J. Arrow 1971). In accordance with most of the literature, we expect risk aversion to be positive: $\overline{M A P}_{D P}-p^{\prime}>0$.

\section{Results}

Table A2 in the Appendix presents summary statistics. It shows the mean MAPs in each decision situation. It also reports the value of $p^{*}$, the likelihood of trustworthiness, for each country. Trustworthiness rates do not vary significantly across countries. ${ }^{6}$

The differences between the mean MAPs provide measures of our three variables of interest: betrayal aversion, social preferences, and risk aversion. Those measures are presented in Table 1. For example, consider betrayal aversion for Americans. On average, Americans require a 22 percentage point better chance of getting the good outcome to trust an agent in the trust game than they do to choose the lottery in the risky dictator game. Our primary goal is to determine whether each of our three preference phenomena is significant in the aggregate once we control for country and gender.

The nonparametric, rank-order-based Mann-Whitney U test indicates that across all six countries, principals are significantly betrayal averse, show little evidence of social preferences, and are risk averse. The aggregate z-scores are 5.37 for betrayal aversion, 1.29 for social preferences,

\footnotetext{
${ }^{6}$ When comparing the trustworthiness rates in Switzerland and Turkey, the two most extreme cases, using a chi ${ }^{2}-$ test, $p=0.16$.
} 
Table 1-Preference Phenomena: Betrayal Aversion, Social Preferences and Risk Aversion

\begin{tabular}{lccc}
\hline \hline & $\begin{array}{c}\text { Betrayal aversion } \\
\left(\overline{M A P}_{T G}-\overline{M A P}_{R D G}\right)\end{array}$ & $\begin{array}{c}\text { Social preferences } \\
\left(\overline{M A P}_{D P}-\overline{M A P}_{R D G}\right)\end{array}$ & $\begin{array}{c}\text { Risk aversion } \\
\left(\overline{M A P}_{D P}-p^{\prime}\right)\end{array}$ \\
\hline All & $0.15^{* * *}$ & 0.05 & $0.16^{* * *}$ \\
Women & $0.14^{* * *}$ & 0.04 & $0.20^{* * * *}$ \\
Men & $0.15^{* * *}$ & 0.06 & $0.13^{* * *}$ \\
Brazil & 0.08 & 0.04 & $0.18^{* * *}$ \\
China & 0.09 & -0.09 & $0.11^{* * *}$ \\
Oman & $0.25^{* * *}$ & 0.12 & $0.30^{* * *}$ \\
Switzerland & $0.11^{*}$ & 0.08 & $0.19^{* * *}$ \\
Turkey & $0.16^{* *}$ & 0.07 & $0.11^{* * *}$ \\
USA & $0.22^{* * *}$ & 0.05 & $0.08^{* * *}$ \\
\hline
\end{tabular}

Notes: * Significant at 10 -percent level; **Significant at 5-percent level; *** Significant at 1-percent level, based on Mann-Whitney U tests.

and 7.04 for risk aversion. ${ }^{7}$ This general pattern applies to both men and women, and most of our countries, although some of the differences lose significance within some groups. Risk aversion is the most robust preference phenomenon across groups, and is significant in each country. Betrayal aversion is found directionally in all countries but is significant in only four, namely Oman, the United States, Turkey, and Switzerland (in decreasing order). Social preferences are not significant in any country.

To examine whether the three preference phenomena in any given country differ from our sample mean, we employed bootstrap methods. From our complete sample, we drew 3,000 random samples of the same size as our observed sample for men and women for each game and country, and calculated the measures for betrayal aversion, social preferences, and risk aversion. Looking at each country relative to the sample, only Oman proved to be an outlier, being more betrayal averse $(p<0.05)$ and more risk averse $(p<0.01)$ than the sample. Once Oman was removed, no country was an outlier on betrayal aversion, but China was less pro-social $(p<0.05)$. Table A3 presents the results.

To probe our data in more detail, we ran OLS-regressions with individual MAPs as the dependent variable (Table 2). Standard errors were adjusted for clustering at the session level. ${ }^{8}$ The independent variables are the three decision scenarios, the countries, gender, age, wealth, and whether a subject majored in economics. The risky dictator game, the United States, and men are our omitted groups.

The regression results generally reproduce the findings of our nonparametric tests. They suggest that betrayal aversion is a robust phenomenon: MAPs in the trust game significantly exceed $M A P$ s in the risky dictator game in each of our specifications. In column 2, we add our demographic control variables. Women demand somewhat higher MAPs than do men, and Omanis are

\footnotetext{
${ }^{7}$ All significance values are for two-tailed tests. This rank-order procedure enables us to control for the effects of gender and countries separately, yet derive an overall measure of our three variables of interest. If the null hypothesis of no difference in subjects' MAPs across the three decision situations were satisfied, the test statistic for each country-gender group would have mean zero, with variance and standard deviation of one. Our test statistics comprise 12 normal deviates. The null would posit their sum to be zero, their variance to be 12 , and their standard deviation to be $\sqrt{12}=3.46$. Adding the $\mathrm{z}$-scores together and dividing by 3.46 gives an aggregate $\mathrm{z}$-score.

${ }^{8}$ Qualitatively similar results are obtained when we use a Tobit model instead. We prefer OLS because it allows us to cluster standard errors at the session level.
} 
Table 2-Determinants of Minimum Acceptable Probabilities (MAPs)

\begin{tabular}{|c|c|c|c|}
\hline & $\begin{array}{l}\text { MAPs } \\
\text { (1) }\end{array}$ & $\begin{array}{l}\text { MAPs } \\
(2)\end{array}$ & $\begin{array}{l}\text { MAPs } \\
\text { (3) }\end{array}$ \\
\hline Trust game & $\begin{array}{l}0.147 * * * \\
(0.036)\end{array}$ & $\begin{array}{l}0.145^{* * *} \\
(0.028)\end{array}$ & $\begin{array}{l}0.143 * * * \\
(0.037)\end{array}$ \\
\hline Decision problem & $\begin{array}{c}0.045 \\
(0.040)\end{array}$ & $\begin{array}{c}0.027 \\
(0.028)\end{array}$ & $\begin{array}{c}0.015 \\
(0.036)\end{array}$ \\
\hline Brazil & & $\begin{array}{c}0.021 \\
(0.027)\end{array}$ & $\begin{array}{c}0.023 \\
(0.028)\end{array}$ \\
\hline China & & $\begin{array}{c}0.065 \\
(0.037)\end{array}$ & $\begin{array}{c}0.068 \\
(0.035)\end{array}$ \\
\hline Oman & & $\begin{array}{l}0.183^{* * * *} \\
(0.042)\end{array}$ & $\begin{array}{c}0.076 \\
(0.095)\end{array}$ \\
\hline Switzerland & & $\begin{array}{c}0.048 \\
(0.025)\end{array}$ & $\begin{array}{c}0.049 \\
(0.028)\end{array}$ \\
\hline Turkey & & $\begin{array}{c}0.007 \\
(0.028)\end{array}$ & $\begin{array}{c}0.009 \\
(0.030)\end{array}$ \\
\hline Women & & $\begin{array}{l}0.078^{* * * *} \\
(0.023)\end{array}$ & $\begin{array}{c}0.097 \\
(0.050)\end{array}$ \\
\hline Age & & $\begin{array}{r}-0.001 \\
(0.002)\end{array}$ & $\begin{array}{r}-0.001 \\
(0.002)\end{array}$ \\
\hline Wealth & & $\begin{array}{r}-0.006 \\
(0.009)\end{array}$ & $\begin{array}{r}-0.005 \\
(0.009)\end{array}$ \\
\hline Economics concentration & & $\begin{array}{r}-0.026 \\
(0.028)\end{array}$ & $\begin{array}{c}-0.029 \\
(0.028)\end{array}$ \\
\hline Trust game $\times$ women & & & $\begin{array}{c}-0.032 \\
(0.062)\end{array}$ \\
\hline Decision prob. $\times$ women & & & $\begin{array}{c}-0.016 \\
(0.064)\end{array}$ \\
\hline Trust game $\times$ Oman & & & $\begin{array}{l}0.137 \\
(0.095)\end{array}$ \\
\hline Decision problem $\times$ Oman & & & $\begin{array}{l}0.167 * * \\
(0.095)\end{array}$ \\
\hline Constant & $\begin{array}{l}0.402 * * * \\
(0.028)\end{array}$ & $\begin{array}{l}0.373 * * * \\
(0.055)\end{array}$ & $\begin{array}{l}0.377 * * * \\
(0.060)\end{array}$ \\
\hline Observations & 494 & 443 & 443 \\
\hline R-squared & 0.06 & 0.14 & 0.15 \\
\hline
\end{tabular}

Notes: Robust standard errors in parentheses, clustered at the session level; ** Significant at 5 percent; *** Significant at 1 percent.

more averse to taking risks than are Americans. ${ }^{9}$ In column 3, we include a number of interaction variables. When we control for the Omanis' somewhat more pronounced degree of betrayal (and risk) aversion, the difference between the $M A P \mathrm{~s}$ in the trust game and the risky dictator game is hardly affected, and remains both economically and statistically significant. We then looked at countries singly (Table A4.). Betrayal aversion is significant in Oman, Switzerland, Turkey, and the United States, but does not reach significance in Brazil and China, as suggested by the nonparametric comparisons.

Let us summarize the results. Our hypothesis regarding betrayal aversion is supported for our complete sample. On a single-country basis, betrayal aversion is positive in all countries but reaches significance only in four. Our bootstrap results show that no country is a significant out-

\footnotetext{
${ }^{9}$ Note that the gender compositions of our control and treatment groups are comparable (50 percent, 48 percent, and 48 percent female subjects for DP, RDG, and TG, respectively). Our gender results are compatible with other experimental studies on risk-taking and trust where women have been found to be more risk averse and less likely to trust strangers than men (for overviews, see Rachel Croson and Uri Gneezy 2004; Eckel and Philip Grossman forthcoming). For a discussion of cross-cultural differences in attitudes to risk, see, e.g., Elke U. Weber and Christopher K. Hsee (2000), and in willingness to trust, e.g., Croson and Nancy Buchan (1999).
} 
lier on betrayal aversion except Oman, where it is more pronounced than in our overall sample. We made no prediction about the sign of social preferences, and find that they are not a robust phenomenon across countries. This may be because inequality aversion tends to counterbalance altruism or efficiency concerns. Alternatively, concerns about others' payoffs and efficiency may simply matter relatively little. Finally, as predicted, MAPs in the decision problem substantially exceed $p^{\prime}$, revealing risk aversion for all groups.

\section{Discussion and Conclusions}

People are less willing to take a risk when another person rather than nature determines the outcome. The goal of this study was to examine whether betrayal aversion is a broad-based phenomenon. Moving beyond the United States, where we ran our earlier study (Bohnet and Zeckhauser 2004), we conducted our experiments in five other countries-Brazil, China, Oman, Switzerland, and Turkey. These countries differ on most important dimensions, e.g., continent, political structure, economic system, culture, religion, and history. We chose these disparate countries to assess the robustness of our results. We consider our approach to be an early, small step toward increasing the "global validity" of laboratory experiments, as we estimate that more than 90 percent of experiments are run with American or Western European subjects.

Our experiments show that people typically sacrifice more expected monetary value to avoid being betrayed than they sacrifice to avoid losing in a lottery offering the same odds and payoffs. Regression analysis finds that none of the five new nations studied differs significantly in its level of betrayal aversion from the United States. Oman has the highest value for betrayal aversion, which according to a bootstrap analysis (without controls), is more pronounced than in our total sample. Brazil and China have the lowest values for betrayal aversion, values that are always positive but never significant. The low value for Brazil may be surprising, as surveys consistently report that its trust rates are among the lowest in the world. Such low trust rates could, however, be due not merely to the confluence of the three preference phenomena studied in this paper, but also due to people's low expectations about others' trustworthiness. Our design, fortunately, allows the principal to set a minimum threshold for trusting, which renders expectations of trustworthiness irrelevant (for rational decision makers). ${ }^{10}$

This paper draws conclusions based on the observed differences in MAPs between the trust game and the risky dictator game. One might argue that in addition to (or in place of) betrayal cost and traditional arguments, other elements could enter a principal's utility function. For example, the controllability of risk has been identified as an important determinant of the perception and the acceptability of natural risks (e.g., Paul Slovic 2000). The literature on controllability in risk taking does not focus, however, on risks due to the choices of another human. Thus, it does not tell us whether a principal perceives the social risks involved in trusting to be less controllable than natural risks. Arguments could be made either way.

Be you Shamus or Shakespeare, betrayal is a central theme of human behavior. Whether in the modern era or the ancient world, agents at times betray their principals. The executives of Enron and Tyco betrayed their shareholders, and Cassius betrayed Caesar. The implications of our findings on betrayal aversion are that shareholders would prefer a 1 percent chance of losing half their value due to a natural catastrophe than a somewhat smaller chance of the same loss due

\footnotetext{
${ }^{10}$ In addition, the trust questions typically used in surveys may simply measure something other than trust expectations, because of the different methodologies or subject pools used. Edward L. Glaeser et al. (2000) and Nava Ashraf, Bohnet, and Nikita Piankov (2006), for example, found that the trust question was more related to experimentally elicited trustworthiness behavior than to trust behavior. For Brazil, Sergio A. Lazzarini et al. (2005) found in investment games (John Berg, John Dickhaut, and McCabe 1995) that Brazilian student subjects were about equally as trusting and as trustworthy as comparable American or Western European subjects.
} 
to the malfeasance of corporate leaders; similarly, political leaders would rather risk a 1 percent chance of dying due to an accident than a 0.8-percent chance of being killed by a subordinate. Betrayal costs are real, and thus require attention in our understanding of decision making.

APPENDIX

A.1 Sample Instructions for the US: Risky Dictator (B.1) and Trust Game (C.1. and C.2) Welcome to research project B.1!

Your code number is: ...........

You are participating in a study in which you will earn some money. The amount will depend on the outcome of a game you will play. At the end of the study, your earnings ( 1 point $=\$ 1$ ) will be added to a show-up fee, and you will be paid in cash.

How the study is conducted. The study is conducted anonymously. Participants will be identified only by code numbers. There is no communication among them. We will call individuals who are in the same role as you "Persons S." You are randomly paired with another person present in this room, call him/her "Person X," whose identity you will never know. Your choice will not be known to other participants or to the researchers.

What the study is about. The study seeks to understand how people decide. You are confronted with two alternatives, A and B. A gives you and Person X a payoff of 10 points for sure. B gives you and Person $\mathrm{X}$ an outcome that depends on a lottery. The lottery can produce option 1 or option 2.

PAYOFF TABLE

\begin{tabular}{lccc}
\hline \hline Result of your decision & Nature of choice & Your earnings & Earnings to Person X \\
\hline A & Certainty & 10 & 10 \\
B & Lottery produces 1 & 15 & 15 \\
& 2 & 8 & 22 \\
\hline
\end{tabular}

The payoff table reads as follows:

If you end up choosing $\mathrm{A}$, you and Person $\mathrm{X}$ will each get 10 points.

If you end up choosing $\mathrm{B}$ and the lottery produces 1 , you and Person $\mathrm{X}$ will get 15 points.

If you end up choosing $\mathrm{B}$ and the lottery produces 2 , you will get 8 points and Person $\mathrm{X}$ will get 22 points.

KEY QUESTION: How large would the probability $p$ of the lottery producing Option 1 minimally have to be for you to pick Alternative B over Alternative A? (like any probability, it must lie between 0 and 1 )

YOUR ANSWER: I choose $B$, if $p$ is at least

Note: You do not know what the actual value of $p$ is. Your choice does not influence the value of p. It is indicated on a sheet of paper in a sealed envelope posted to the blackboard. With YOUR ANSWER you indicate how large $p$ has to be before you pick B over A.

- new page -

Conduct of the study B.1.

1. While you answer the KEY QUESTION, we will post the envelope containing the value of $p$ on the blackboard. After you have decided, we will collect the answer forms. Please fold them so that nobody can see YOUR ANSWER.

2. We will then open the envelope and inform everyone of the value of $\mathrm{p}$ for this experiment. This gives you $\mathrm{p}^{*}$, the probability of receiving option 1 .

3. If $\mathbf{p}^{*}$ is greater than or equal to your required value of $\mathbf{p}$ (from YOUR ANSWER above), we will follow your instructions: Your earnings will be determined by the outcome of the lottery. 
We will create and then conduct the lottery. We will put green and blue marbles into a bowl. Out of all marbles in the bowl, the percentage of green marbles will be the same as $\mathrm{p}^{*}$. The remaining marbles will be blue. We will then randomly pull a ball from the bowl.

a. If the marble is green, you and your Person $\mathrm{X}$ will get 15 points each.

b. If the marble is blue, you will get 8 points and your Person $X$ will get 22 points.

4. If $p^{*}$ is less than your required value of $p$ (from YOUR ANSWER above), we will follow your instructions: You and your Person $\mathrm{X}$ will get Certainty A, namely 10 points each.

\section{Completion of Study and Earnings.}

- Before we conduct the study, we ask you to complete a pre-study questionnaire. We will start the study once everyone has correctly filled out this questionnaire.

- 1 point $=\$ 1$. You can collect your earnings by presenting your CODE NUMBER FORM at the end of the study. Your earnings will be in an envelope marked with your code number.

—new page-

Welcome to research project C.1!

Your code number is: ...........

You are participating in a study in which you will earn some money. The amount will depend on the outcome of a game you will play. At the end of the study, your earnings ( 1 point $=\$ 1$ ) will be added to a show-up fee, and you will be paid in cash.

How the study is conducted. The study is conducted anonymously. Participants will be identified only by code numbers. There is no communication among them. We will call individuals who are in the same role as you "Persons S." You are randomly paired with another person present in this room, call him/her "Person Y," whose identity you will never know. Neither your choice nor Y's choice will be known to other participants or to the researchers.

What the study is about. The study seeks to understand how people decide. You are confronted with two alternatives, A and B. A gives you a payoff for sure and Person Y takes no action. B gives you an outcome that depends on Person Y's behavior. Person Y chooses between options 1 and 2 .

PAYOFF TABLE

\begin{tabular}{lccc}
\hline \hline Result of your decision & Nature of choice & Your earnings & Earnings to Person Y \\
\hline A & Certainty & 10 & 10 \\
B & Person Y chooses 1 & 15 & 15 \\
& 2 & 8 & 22 \\
\hline
\end{tabular}

The payoff table reads as follows:

If you end up choosing A, you and Person $\mathrm{Y}$ will each get 10 points.

If you end up choosing B and Person $Y$ chooses 1, you and Person $Y$ will each get 15 points.

If you end up choosing $\mathrm{B}$ and Person $\mathrm{Y}$ chooses 2, you will get 8 points and Person $\mathrm{Y}$ will get 22 points.

KEY QUESTION: How large would the probability $p$ of being paired with a Person Y who chose Option 1 minimally have to be for you to pick Alternative B over Alternative A? (like any probability, it must lie between 0 and 1 )

YOUR ANSWER: I choose $B$ if $p$ is at least

Note: You do not know what the actual value of p is. Your choice does not influence the value of p. It is determined by the fraction of Persons Y choosing Option 1. With YOUR ANSWER you indicate how large the fraction of Persons $Y$ who choose 1 has to be before you pick B over $A$. Conduct of the study C.1. 
1. While you answer the KEY QUESTION, each of the individuals playing Persons Y have to answer the following question: "Which option, 1 or 2, do you choose in case B?" After you and all Persons Y have decided, we will collect the answer forms. Please fold them so that nobody can see YOUR ANSWER.

2. We will then calculate the percentage of Persons $Y$ who chose option 1 and inform everyone of it. This gives you $\mathrm{p}^{*}$, the probability of being paired with a Person Y who chose option 1.

3. If $p^{*}$ is greater than or equal to your required value of $p$ (from YOUR ANSWER above), we will follow your instructions. Your earnings will be determined by your Person Y's choice.

a. If your Person Y chose 1, you and your Person Y will get 15 points each.

b. If your Person Y chose 2, you will get 8 points and your Person Y will get 22 points.

4. If $p^{*}$ is less than your required value of $p$ (from YOUR ANSWER above), we will follow your instructions: You and your Person $Y$ will get Certainty A, namely 10 points each.

\section{Completion of Study and Earnings.}

- Before we conduct the study, we ask you to complete a pre-study questionnaire. We will start the study once everyone has correctly filled out this questionnaire.

- 1 point $=\$ 1$. You can collect your earnings by presenting your CODE NUMBER FORM at the end of the study. Your earnings will be in an envelope marked with your code number.

Welcome to research project C.2!

Your code number is: ............

You are participating in a study in which you will earn some money. The amount will depend on the outcome of a game you will play. At the end of the study, your earnings ( 1 point $=\$ 1$ ) will be added to a show-up fee, and you will be paid in cash.

How the study is conducted. The study is conducted anonymously. Participants will be identified only by code numbers. There is no communication among the participants. We will call individuals who are in the same role as you "Persons Y." You are randomly paired with another person present in this room, call him/her "Person S," whose identity you will never know. Neither your choice nor S's choice will be known to other participants or to the researchers.

What the study is about. The study seeks to understand how people decide. Person S is confronted with two alternatives, A and B. A gives you and Person S a payoff for sure. You do not take any action. If Person S's decision results in B, you have to choose one of two options, 1 or 2.

PAYOFF TABLE

\begin{tabular}{lccc}
\hline \hline Result of Person S's decision & Nature of choice & Your earnings & Earnings to Person S \\
\hline A & Certainty & 10 & 10 \\
B & You choose 1 & 15 & 15 \\
& 2 & 22 & 8 \\
\hline
\end{tabular}

The payoff table reads as follows:

If Person S's decision results in A, you and Person S will each get 10 points.

If Person S's decision results in B and you choose 1, you and Person S will each get 15 points.

If Person S's decision results in B and you choose 2, you will get 22 points and Person S will get 8 points.

KEY QUESTION: Which option, 1 or 2 , do you choose in case B?

YOUR ANSWER: I choose

After you have answered this question, we will collect your answer form. 
-new page-

[Distributed after Persons Y have made their decisions and handed in their forms.]

Conduct of the study C.2.

1. Persons $\mathrm{S}$ have to answer the following question: "How large would the probability of being paired with a Person Y who chose option 1 minimally have to be for you to pick B over A? (like any probability, it must lie between 0 and 1)" After all Persons $S$ have decided, we will collect their answer forms.

2. Based on your and all other Persons Y's choices, we will then calculate the percentage of Persons $\mathrm{Y}$ who chose option 1 and inform everyone of it. This gives us $\mathrm{p}^{*}$, the probability that a Person S will be paired with a Person Y who chose option 1.

3. If $p^{*}$ is greater than or equal to the value of $p$ required by your Person $S$, then YOUR ANSWER from above will determine the final earnings.

a. If you chose 1 , you and your Person $\mathrm{S}$ will each get 15 points.

b. If you chose 2 , you will get 22 points and Person $S$ will get 8 points.

4. If $p^{*}$ is less than the value of $p$ required by your Person $S$, then you and your Person $S$ will each get Certainty $\mathrm{A}$, namely 10 points each.

\section{Completion of Study and Earnings.}

- Before we conduct the study, we ask you to complete a pre-study questionnaire. We will start the study once everyone has correctly filled out this questionnaire.

- 1 point $=\$ 1$. You can collect your earnings by presenting your CODE NUMBER FORM at the end of the study. Your earnings will be in an envelope marked with your code number.

Table A.2-MAPS in Three Decision Situations

\begin{tabular}{|c|c|c|c|}
\hline & Trust game & Risky dictator game & Decision problem \\
\hline \multicolumn{4}{|l|}{$\overline{\mathrm{A} 11}$} \\
\hline Mean & 0.55 & 0.40 & 0.45 \\
\hline Median & 0.60 & 0.35 & 0.40 \\
\hline Standard Deviation & 0.26 & 0.26 & 0.24 \\
\hline$N$ & [190] & [149] & {$[155]$} \\
\hline \multicolumn{4}{|l|}{ Women } \\
\hline Mean & 0.59 & 0.45 & 0.49 \\
\hline Median & 0.65 & 0.48 & 0.50 \\
\hline Standard Deviation & 0.25 & 0.28 & 0.25 \\
\hline$N$ & {$[91]$} & [70] & {$[73]$} \\
\hline \multicolumn{4}{|l|}{$\overline{\text { Men }}$} \\
\hline Mean & 0.51 & 0.36 & 0.42 \\
\hline Median & 0.50 & 0.30 & 0.37 \\
\hline Standard Deviation & 0.25 & 0.22 & 0.22 \\
\hline$N$ & [98] & {$[77]$} & {$[72]$} \\
\hline \multicolumn{4}{|l|}{$\overline{\operatorname{Brazil}\left(p^{*}=0.35\right)}$} \\
\hline Mean & 0.51 & 0.43 & 0.47 \\
\hline Median & 0.50 & 0.38 & 0.49 \\
\hline Standard Deviation & 0.29 & 0.31 & 0.30 \\
\hline$N$ & [49] & {$[32]$} & [30] \\
\hline \multicolumn{4}{|l|}{$\overline{\text { China }\left(p^{*}=0.29\right)}$} \\
\hline Mean & 0.58 & 0.49 & 0.40 \\
\hline Median & 0.65 & 0.55 & 0.40 \\
\hline Standard Deviation & 0.22 & 0.27 & 0.17 \\
\hline$N$ & {$[21]$} & {$[21]$} & [24] \\
\hline \multicolumn{4}{|l|}{$\overline{\operatorname{Oman}}\left(p^{*}=0.32\right)$} \\
\hline Mean & 0.72 & 0.47 & 0.59 \\
\hline Median & 0.80 & 0.45 & 0.70 \\
\hline Standard Deviation & 0.21 & 0.20 & 0.27 \\
\hline$N$ & [29] & {$[22]$} & {$[24]$} \\
\hline
\end{tabular}


TABLE A.2-Continued.

\begin{tabular}{lccc}
\hline \hline & Trust game & Risky dictator game & Decision problem \\
\hline SWI $\left(p^{*}=0.28\right)$ & 0.51 & 0.40 & 0.48 \\
Mean & 0.51 & 0.42 & 0.50 \\
Median & 0.21 & 0.22 & 0.22 \\
Standard Deviation & {$[25]$} & {$[24]$} & {$[22]$} \\
$N$ & & & \\
TUR $\left(p^{*}=0.46\right)$ & 0.49 & 0.33 & 0.40 \\
Mean & 0.50 & 0.29 & 0.43 \\
Median & 0.25 & 0.28 & 0.21 \\
Standard Deviation & {$[35]$} & {$[21]$} & {$[30]$} \\
$N$ & & & 0.37 \\
United States $\left(p^{*}=0.29\right)$ & 0.54 & 0.32 & 0.30 \\
Mean & 0.60 & 0.29 & 0.15 \\
Median & 0.24 & 0.21 & {$[25]$} \\
Standard Deviation & {$[31]$} & {$[29]$} & \\
$N$ & & & \\
\hline
\end{tabular}

Notes: $N=$ number of independent observations. Values for $N$ in the table do not include the second player in the trust and risky dictator games. Note, 1 subject in the trust game, 2 subjects in the risky dictator game and 10 subjects in the decision problem did not indicate their gender.

Table A.3-Bootstrap Results for the Three Preference Phenomena:

Percent of Randomly Drawn Sub-Samples Smaller than the Experimentally Observed Country Sample

\begin{tabular}{lccc}
\hline \hline & $\begin{array}{c}\text { Betrayal aversion } \\
\left(M A P_{\mathrm{TG}}-M A P_{\mathrm{RDG}}\right)\end{array}$ & $\begin{array}{c}\text { Social preferences } \\
\left(M A P_{\mathrm{DP}}-M A P_{\mathrm{RDG}}\right)\end{array}$ & $\begin{array}{c}\text { Risk aversion } \\
\left(M A P_{\mathrm{DP}}-0.29\right)\end{array}$ \\
\hline Brazil & 9.67 & 47.34 & 73.04 \\
China & 21.30 & 2.47 & 15.00 \\
Oman & 95.34 & 86.77 & 99.94 \\
Switzerland & 28.00 & 70.20 & 66.74 \\
Turkey & 51.90 & 63.93 & 11.37 \\
United States & 88.27 & 53.20 & 2.97 \\
\hline
\end{tabular}

Table A.4-Determinants of Minimum Acceptable Probabilities (MAPs) in Each Country

\begin{tabular}{lcccccc}
\hline \hline & Brazil & China & Oman & Switz & Turkey & $\begin{array}{c}\text { United } \\
\text { States }\end{array}$ \\
\hline Trust game & 0.104 & 0.075 & $0.241^{* * *}$ & $0.141^{* *}$ & $0.147^{* *}$ & $0.233^{* * * *}$ \\
& $(0.076)$ & $(0.073)$ & $(0.080)$ & $(0.063)$ & $(0.066)$ & $(0.055)$ \\
Decision pr. & -0.019 & -0.091 & 0.157 & 0.107 & 0.041 & 0.019 \\
& $(0.081)$ & $(0.069)$ & $(0.088)$ & $(0.065)$ & $(0.073)$ & $(0.057)$ \\
Women & 0.012 & 0.003 & 0.058 & $0.153^{* * *}$ & $0.235^{* * *}$ & 0.082 \\
& $(0.062)$ & $(0.064)$ & $(0.066)$ & $(0.055)$ & $(0.059)$ & $(0.046)$ \\
Age & 0.002 & -0.013 & 0.019 & -0.015 & -0.018 & $-0.013^{* *}$ \\
& $(0.005)$ & $(0.017)$ & $(0.022)$ & $(0.008)$ & $(0.018)$ & $(0.006)$ \\
Wealth & -0.042 & 0.014 & 0.006 & 0 & 0.007 & -0.017 \\
& $(0.037)$ & $(0.031)$ & $(0.036)$ & $(0.035)$ & $(0.035)$ & $(0.021)$ \\
Economics & 0.034 & 0.033 & -0.052 & -0.035 & $-0.148^{* *}$ & -0.104 \\
& $(0.073)$ & $(0.067)$ & $(0.088)$ & $(0.055)$ & $(0.059)$ & $(0.069)$ \\
Constant & $0.485^{* *}$ & 0.742 & 0.021 & $0.655^{* * *}$ & 0.66 & $0.657^{* * *}$ \\
& $(0.185)$ & $(0.419)$ & $(0.495)$ & $(0.246)$ & $(0.417)$ & $(0.164)$ \\
Obs. & 103 & 66 & 59 & 68 & 69 & 78 \\
R-squared & 0.04 & 0.14 & 0.21 & 0.19 & 0.3 & 0.27 \\
\hline
\end{tabular}

Note: Robust standard errors in parentheses, clustered at the session level; ** Significant at 5-percent; *** Significant at 1-percent. 


\section{REFERENCES}

Andreoni, James, and John Miller. 2002. "Giving According to GARP: An Experimental Test of the Consistency of Preferences for Altruism." Econometrica, 70(2): 737-53.

Arrow, Kenneth J. 1971. Essays in the Theory of Risk Bearing. Chicago: Markham.

- Ashraf, Nava, Iris Bohnet, and Nikita Piankov. 2006. "Decomposing Trust and Trustworthiness." Experimental Economics, 9(3): 193-208.

- Berg, Joyce, John W. Dickhaut, and Kevin A. McCabe. 1995. "Trust, Reciprocity, and Social History." Games and Economic Behavior, 10(1): 122-42.

-Blount, Sally. 1995. "When Social Outcomes Aren't Fair: The Effect of Causal Attributions on Preferences." Organizational Behavior and Human Decision Processes, 63(2): 131-44.

-Bohnet, Iris, and Richard Zeckhauser. 2004. "Trust, Risk and Betrayal." Journal of Economic Behavior and Organization, 55(4): 467-84.

-Bolton, Gary E., and Axel Ockenfels. 2000. "ERC: A Theory of Equity, Reciprocity, and Competition." American Economic Review, 90(1): 166-93.

Camerer, Colin, and Keith Weigelt. 1988. "Experimental Tests of a Sequential Equilibrium Reputation Model." Econometrica, 56(1): 1-36.

-Charness, Gary, and Matthew Rabin. 2002. "Understanding Social Preferences with Simple Tests." Quarterly Journal of Economics, 117(3): 817-69.

Chugh, Dolly, and Max H. Bazerman. 2007. "Bounded Awareness: What You Fail to See Can Hurt You." Mind and Society, 6(1): 1-18.

-Croson, Rachel, and Nancy Buchan. 1999. "Gender and Culture: International Experimental Evidence from Trust Games." American Economic Review, 89(2): 386-91.

Croson, Rachel, and Uri Gneezy. 2004. "Gender Differences in Preferences." University of Pennsylvania, Wharton School, Working Paper.

Dufwenberg, Martin, and Georg Kirchsteiger. 2004. "A Theory of Sequential Reciprocity." Games and Economic Behavior, 47(2): 268-98.

Eckel, Catherine C., and Philip Grossman. Forthcoming. "Men, Women and Risk Aversion: Experimental Evidence." In Handbook of Experimental Economic Results, ed. Charles Plott, and Vernon Smith. New York: Elsevier.

Eckel, Catherine C., and Rick K. Wilson. 2004. “Is Trust a Risky Decision?” Journal of Economic Behavior and Organization, 55(4): 447-65.

-Ellsberg, Daniel. 1961. "Risk, Ambiguity and the Savage Axioms." Quarterly Journal of Economics, 75 (4): 643-69.

-Falk, Armin, and Urs Fischbacher. 2006. "A Theory of Reciprocity." Games and Economic Behavior, 54(2): 293-315.

-Fehr, Ernst, and Klaus M. Schmidt. 1999. “A Theory of Fairness, Competition, and Cooperation.” Quarterly Journal of Economics, 114(3): 817-68.

Fehr, Ernst, and Klaus M. Schmidt. 2002. "Theories of Fairness and Reciprocity: Evidence and Economic Applications." In Advances in Economics and Econometrics: 8th World Congress, Econometric Society Monographs, ed. M. Dewatripont and S. Turnovsky, 208-57. Cambridge, MA: Cambridge University Press.

-Fehr, Ernst, Urs Fischbacher, and Michael Kosfeld. 2005. "Neuroeconomic Foundations of Trust and Social Preferences: Initial Evidence.” American Economic Review, 95(2): 346-51.

Frey, Bruno S., Matthias Benz, and Alois Stutzer. 2004. "Introducing Procedural Utility: Not Only What, but Also How Matters." Journal of Institutional and Theoretical Economics, 160(3): 377-401.

-Glaeser, Edward L., David I. Laibson, Jose A. Scheinkman, and Christine L. Soutter. 2000. "Measuring Trust." Quarterly Journal of Economics, 115(3): 811-46.

Heider, Fritz. 1958. The Psychology of Interpersonal Relations. New York: Wiley.

Henrich, Joseph, Robert Boyd, Samuel Bowles, Colin Camerer, Ernst Fehr, and Herbert Gintis, ed. 2004. Foundations of Human Sociality: Oxford: Oxford University Press.

Knack, Stephen, and Philip Keefer. 1997. "Does Social Capital Have an Economic Payoff? A Cross-Country Investigation." Quarterly Journal of Economics, 112(4): 1251-88.

Koehler, Jonathan J., and Andrew Gershoff. 2003. "Betrayal Aversion: When Agents of Protection Become Agents of Harm." Organizational Behavior and Human Decision Processes, 90(2): 244-61.

Kosfeld, Michael, Markus Heinrichs, Paul J. Zak, Urs Fischbacher, and Ernst Fehr. 2005. "Oxytocin Increases Trust in Humans." Nature, 435(2): 673-76. 
Kreps, David. 1990. “Corporate Culture and Economic Theory.” In Perspectives on Positive Political Economy, ed. James E. Alt and Kenneth A. Shepsle, 90-143. Cambridge: Cambridge University Press.

Kruglanski, Arie W. 1979. "Causal Explanation, Teleological Explanation: On Radical Particularism in Attribution Theory." Journal of Personality and Social Psychology, 37(9): 1447-57.

Kunda, Ziva. 1999. Social Cognition. Cambridge, MA: MIT Press.

La Porta, Rafael, Florencio Lopez-de-Silanes, Andrei Shleifer, and Robert W. Vishney. 1997. "Trust in Large Organizations." American Economic Review, 87(2): 333-38.

Lazzarini, Sergio G., Regina Madalozzo, Rinaldo Artes, and Jose de Oliveira Siqueira. 2005. "Measuring Trust: An Experiment in Brazil." Economia Aplicada/Brazilian Journal of Applied Economics, 9(2): 153-69.

McCabe, Kevin A., Mary L. Rigdon, and Vernon L. Smith. 2003. "Positive Reciprocity and Intentions in Trust Games." Journal of Economic Behavior and Organization, 52(2): 267-75.

Pratt, John W. 1964. "Risk Aversion in the Small and in the Large." Econometrica, 32(1-2): 122-36.

Rabin, Matthew. 1993. "Incorporating Fairness into Game Theory and Economics." American Economic Review, 83(5): 1281-1302.

Robinson, Sandra L., and Elizabeth Wolfe Morrison. 2000. "The Development of Psychological Contract Breach and Violation: A Longitudinal Study." Journal of Organizational Behavior, 21(5): 525-46.

Roth, Alvin E., Vesna Prasnikar, Masahiro Okuno-Fujiwara, and Shmuel Zamir. 1991. "Bargaining and Market Behavior in Jerusalem, Ljubljana, Pittsburgh, and Tokyo: An Experimental Study." American Economic Review, 81(5): 1068-95.

Slovic, Paul. 2000. The Perception of Risk. London: Earthscan.

Weber, Elke U., and Christopher K. Hsee. 2000. "Culture and Individual Judgment and Decision Making." Applied Psychology: An International Review, 49(1): 32-61. 


\section{This article has been cited by:}

1. Gary Bolton, Axel Ockenfels, Julia Stauf. 2014. Social responsibility promotes conservative risk behavior. European Economic Review . [CrossRef]

2. Steven J. Kachelmeier, Tracie Majors, Michael G. Williamson. 2014. Does Intent Modify Risk-Based Auditing?. The Accounting Review 89, 2181-2201. [CrossRef]

3. Özalp Özer, Yanchong Zheng, Yufei Ren. 2014. Trust, Trustworthiness, and Information Sharing in Supply Chains Bridging China and the United States. Management Science 60. . [CrossRef]

4. James S. Ang, Zhiqian Jiang, Chaopeng Wu. 2014. Good Apples, Bad Apples: Sorting Among Chinese Companies Traded in the U.S. Journal of Business Etbics . [CrossRef]

5. Mariko J. Klasing. 2014. Cultural change, risk-taking behavior and implications for economic development. Journal of Development Economics 110, 158-169. [CrossRef]

6. Evgeniya Lukinova, Mikhail Myagkov, Pavel Shishkin. 2014. The value of sociality. foresight 16, 309-328. [CrossRef]

7. Marina Bianchi. 2014. Willingness to believe and betrayal aversion: the special role of trust in art exchanges. Journal of Cultural Economics . [CrossRef]

8. Leonardo Becchetti, Maurizio Fiaschetti, Giancarlo Marini. 2014. Card games and economic behavior. Games and Economic Bebavior. [CrossRef]

9. Werner Güth, Harriet Mugera, Andrew Musau, Matteo Ploner. 2014. Deterministic versus probabilistic consequences of trust and trustworthiness: An experimental investigation. Journal of Economic Psychology 42, 28-40. [CrossRef]

10. Swee-Hoon Chuah, Robert Hoffmann, Jeremy Larner. 2014. Chinese values and negotiation behaviour: A bargaining experiment. International Business Review . [CrossRef]

11. Kei Tsutsui, Daniel John Zizzo. 2014. Group status, minorities and trust. Experimental Economics 17, 215-244. [CrossRef]

12. Swee-Hoon Chuah, Robert Hoffmann, Jeremy Larner. 2014. Elicitation effects in a multi-stage bargaining experiment. Experimental Economics 17, 335-345. [CrossRef]

13. James C. Cox, Vjollca Sadiraj, Ulrich Schmidt. 2014. Paradoxes and mechanisms for choice under risk. Experimental Economics . [CrossRef]

14. Ann-Christin Posten, Axel Ockenfels, Thomas Mussweiler. 2014. How activating cognitive content shapes trust: A subliminal priming study. Journal of Economic Psychology 41, 12-19. [CrossRef]

15. J. A. Aimone, D. Houser, B. Weber. 2014. Neural signatures of betrayal aversion: an fMRI study of trust. Proceedings of the Royal Society B: Biological Sciences 281, 20132127-20132127. [CrossRef]

16. Juan A. Lacomba, Francisco Lagos, Ernesto Reuben, Frans van Winden. 2014. On the escalation and de-escalation of conflict. Games and Economic Bebavior . [CrossRef]

17. Ferdinand M. Vieider, Thorsten Chmura, Tyler Fisher, Takao Kusakawa, Peter Martinsson, Frauke Mattison Thompson, Adewara Sunday. 2014. Within- versus between-country differences in risk attitudes: implications for cultural comparisons. Theory and Decision . [CrossRef]

18. L. Becchetti, P. Conzo, A. Romeo. 2014. Violence, trust, and trustworthiness: evidence from a Nairobi slum. Oxford Economic Papers 66, 283-305. [CrossRef]

19. S. Altmann, A. Falk, A. Grunewald, D. Huffman. 2014. Contractual Incompleteness, Unemployment, and Labour Market Segmentation. The Review of Economic Studies 81, 30-56. [CrossRef]

20. Kota Saito. 2013. Social Preferences under Risk: Equality of Opportunity versus Equality of Outcome. American Economic Review 103:7, 3084-3101. [Abstract] [View PDF article] [PDF with links] 
21. Paola Sapienza, Anna Toldra-Simats, Luigi Zingales. 2013. Understanding Trust. The Economic Journal 123:10.1111/ecoj.2013.123.issue-573, 1313-1332. [CrossRef]

22. Juan Camilo Cárdenas, Alberto Chong, Hugo Nopo. 2013. Stated social behavior and revealed actions: Evidence from six Latin American countries. Journal of Development Economics 104, 16-33. [CrossRef]

23. Dustin Tingley. 2013. Face-Off: Facial Features and Strategic Choice. Political Psychology n/a-n/a. [CrossRef]

24. Jason A. Aimone, Daniel Houser. 2013. Harnessing the benefits of betrayal aversion. Journal of Economic Bebavior \& Organization 89, 1-8. [CrossRef]

25. John T. Kulas, Mana Komai, Philip J. Grossman. 2013. Leadership, information, and risk attitude: A game theoretic approach. The Leadership Quarterly 24, 349-362. [CrossRef]

26. Leonardo Becchetti, Stefano Castriota, Pierluigi Conzo. 2013. Cooperative Membership as a Trust and Trustworthiness Reinforcing Device: Results from a Field Experiment in the Philippines. Journal of Development Studies 49, 412-425. [CrossRef]

27. W. De Neys, A. Hopfensitz, J.-F. Bonnefon. 2013. Low second-to-fourth digit ratio predicts indiscriminate social suspicion, not improved trustworthiness detection. Biology Letters 9, 20130037-20130037. [CrossRef]

28. J. van Honk, C. Eisenegger, D. Terburg, D. J. Stein, B. Morgan. 2013. Generous economic investments after basolateral amygdala damage. Proceedings of the National Academy of Sciences 110, 2506-2510. [CrossRef]

29. J. Michelle Brock,, Andreas Lange,, Erkut Y. Ozbay. 2013. Dictating the Risk: Experimental Evidence on Giving in Risky Environments. American Economic Review 103:1, 415-437. [Abstract] [View PDF article] [PDF with links]

30. Jason A. Aimone, Daniel Houser. 2012. What you don't know won't hurt you: a laboratory analysis of betrayal aversion. Experimental Economics 15, 571-588. [CrossRef]

31. Alpaslan Akay, Peter Martinsson, Haileselassie Medhin, Stefan T. Trautmann. 2012. Attitudes toward uncertainty among the poor: an experiment in rural Ethiopia. Theory and Decision 73, 453-464. [CrossRef]

32. Steffen Huck, Gabriele K. Lünser, Jean-Robert Tyran. 2012. Competition fosters trust. Games and Economic Behavior 76, 195-209. [CrossRef]

33. Christian Thöni, Jean-Robert Tyran, Erik Wengström. 2012. Microfoundations of social capital. Journal of Public Economics 96, 635-643. [CrossRef]

34. Samuel Bowles, Sandra Polanía-Reyes. 2012. Economic Incentives and Social Preferences: Substitutes or Complements?. Journal of Economic Literature 50:2, 368-425. [Abstract] [View PDF article] [PDF with links]

35. Kiridaran Kanagaretnam, Stuart Mestelman, S.M. Khalid Nainar, Mohamed Shehata. 2012. The impact of empowering investors on trust and trustworthiness. Journal of Economic Psychology 33, 566-577. [CrossRef]

36. Gregor Hasler. 2012. Can the neuroeconomics revolution revolutionize psychiatry?. Neuroscience \& Biobehavioral Reviews 36, 64-78. [CrossRef]

37. Jacob G. Birnberg, Yue (May) Zhang. 2011. When Betrayal Aversion Meets Loss Aversion: The Effects of Changes in Economic Conditions on Internal Control System Choices. Journal of Management Accounting Research 23, 169-187. [CrossRef]

38. Ingrid M. T. Rohde, Kirsten I. M. Rohde. 2011. Risk attitudes in a social context. Journal of Risk and Uncertainty . [CrossRef] 
39. Detlef Fetchenhauer, David Dunning. 2011. Betrayal aversion versus principled trustfulness-How to explain risk avoidance and risky choices in trust games. Journal of Economic Bebavior \& Organization . [CrossRef]

40. D. Serra. 2011. Combining Top-Down and Bottom-Up Accountability: Evidence from a Bribery Experiment. Journal of Law, Economics, and Organization . [CrossRef]

41. Maria Vittoria Levati, Topi Miettinen, Birendra Rai. 2011. Context and Interpretation in Laboratory Experiments: The Case of Reciprocity. Journal of Economic Psychology . [CrossRef]

42. Tom Redman, Graham Dietz, Ed Snape, Wieke van der Borg. 2011. Multiple constituencies of trust: a study of the Oman military. The International Journal of Human Resource Management 22, 2384-2402. [CrossRef]

43. Noel D. Johnson, Alexandra A. Mislin. 2011. Trust Games: A Meta-Analysis. Journal of Economic Psychology . [CrossRef]

44. John J. Horton, David G. Rand, Richard J. Zeckhauser. 2011. The online laboratory: conducting experiments in a real labor market. Experimental Economics . [CrossRef]

45. Janice Boucher Breuer, John McDermott. 2011. Culture, caution, and trust. Journal of Development Economics . [CrossRef]

46. Luigi Guiso, Paola Sapienza, Luigi ZingalesCivic Capital as the Missing Link 417-480. [CrossRef]

47. Marco Castillo, Gregory Leo. 2010. Moral Hazard and Reciprocity. Southern Economic Journal 77, 271-281. [CrossRef]

48. Michel S. Zouboulakis. 2010. Trustworthiness as a Moral Determinant of Economic Activity: Lessons from the Classics. Forum for Social Economics 39, 209-221. [CrossRef]

49. S. Gachter, B. Herrmann, C. Thoni. 2010. Culture and cooperation. Philosophical Transactions of the Royal Society B: Biological Sciences 365, 2651-2661. [CrossRef]

50. Marie-Laure Cabon-Dhersin, Nathalie Etchart-Vincent. 2010. The puzzle of cooperation in a game of chicken: an experimental study. Theory and Decision . [CrossRef]

51. Simon Gächter. 2010. (Dis)advantages of student subjects: What is your research question?. Bebavioral and Brain Sciences 33, 92-93. [CrossRef]

52. Gary E. Bolton,, Axel Ockenfels. 2010. Betrayal Aversion: Evidence from Brazil, China, Oman, Switzerland, Turkey, and the United States: Comment. American Economic Review 100:1, 628-633. [Abstract] [View PDF article] [PDF with links]

53. John Ermisch, Diego Gambetta, Heather Laurie, Thomas Siedler, S. C. Noah Uhrig. 2009. Measuring people's trust. Journal of the Royal Statistical Society: Series A (Statistics in Society) 172:10.1111/ rssa.2009.172.issue-4, 749-769. [CrossRef]

54. B. Kelsey Jack. 2009. Upstream-downstream transactions and watershed externalities: Experimental evidence from Kenya\#. Ecological Economics 68, 1813-1824. [CrossRef]

55. Ernst FehrSocial Preferences and the Brain 215-232. [CrossRef]

56. İ. Erdem SeçilmişA Survey of Game Theory Applications in Turkey 155-168. [CrossRef] 